\title{
Tolerance and Persecution as a Threat to the Unity of the Nation
}

\author{
Perception and attitude of the people in Bandung and Kabupaten Bandung
}

\author{
Endang Danial Ar \\ Civic Education \\ Universitas Pendidikan Indonesia \\ Bandung, Indonesia \\ endangdanial@upi.edu
}

\begin{abstract}
There is a significant relation between attitude of social tolerance and the onset of the persecution of the community. Persecution is a new phenomenon that is considered by society as a punishment against those who are accused of committing the violation of norms, rules, laws, in the community. This phenomenon is considered to be 'terror' who threaten the journey of this nation. This study focuses on how the description of the people in Bandung and Kabupaten Bandung perceive and respond to persecution. Because the incidents of the persecution that happens in the community is very closely related to a person's attitudes and perceptions. Similarly, the attitude of their tolerance. Especially residents in urban areas (Kota Bandung) and around the country side (Kabupaten Bandung). This research approach is quantitative descriptive, correlational approach. The main data collecting tool was the question form, scale, attitude documents, plus interviews and observations. Calculation and analysis of the data processing is carried out with the help of statistics. The results showed that the knowledge and attitude of tolerance towards the behavior of persecution had a significant relationship. It means an increase in knowledge and attitudes tolerant society tendencies are reducing behavior of persecution, so it is necessary of socialization and information of rules/laws that exist, as well as foster the creation of harmony and unity of the nation
\end{abstract}

Keywords - tolerance; persecution; urban; rural

\section{INTRODUCTION}

In modern society and the traditional issues of vigilantism could not be tolerated, according to the Chairman of The Foundation of the Indonesian Legal Aid Institute (YLBHI) Asfinawati it was not an ordinary criminal, but a very serious problem [1]. This is because society has been acting as police this is because society has been acting as police (raided), Act as Prosecutor Act as Prosecutor (declare others guilty) and acting as a judge (deciding other people guilty and punish), this clearly violates the law. This clearly violates the law. Indonesia as a State of law, according to officials of the Police Department's, the citizens should not be vigilantism. According to psychologists' expert Hamdi Muluk this is describing the low public confidence towards the social institution, either legal or law enforcement agencies, which can bring justice [2]. Nowadays social and technology development was very quickly, have not been able followed by increased awareness of the law and tolerance in society. The problem of the research is how the attitude of persecution of the community in the city and the rural? Is the persecution causes by the disobedience of the law? is it causes by low attitude of tolerance of the citizens. Theoretically if citizens cannot accept and hold the norms and rules as the rules of the game, then all sorts of persecution can arise. According to the experts, the process of transformation of society towards a modern society that is aware of the rule of law and tolerance of the citizens is not easy. Primitive figures who are still attached to most citizens in Indonesia such as the vigilante was an old time phenomenon, but re-emerged with new characteristics [3]. Research of Hamdi Muluk declare the appearance of persecution in the community more daring en masse rather than individually [2]. There is no feeling of being tolerant and irrational. In the developed world persecution are frequent resulting of suffering. ..are all factors that may establish persecution, but not all suffering will necessarily establish persecution. The suffering experienced by the victim must be sufficiently severe [4]. Unity of the nation is the social forces that were built with public trust and other components in it as the foundation. The trust can arise when there is mutual appreciation, respect, and recognizing differences, and also realize the function between fellow citizens. The role and function of social institutions, which can guarantee comfort, security, tribal and religious diversity, and the interests of society.

\section{THEORITICAL}

Understanding of the tolerant is about understanding restrictions of a social attitude of a person or group toward specific social situations and conditions. Therefore, social tolerance is more on the study of social psychology. Someone's social attitude could appear positive or negative. People who are aware of attitude differences between him and others will appear tolerant. It means to recognize, realize, respect for differences. Do not force other to accept, or impose others same with him. 


\section{A. Tolerance}

Right to have different opinion with other people is usual. But if you disagree, don't communicate with arrogant even when its right, because it will make some discomfort in social communication. This happens a lot in the context of political life, ethics, and religion. Michael W Austin says that ....The capacity to disagree strongly with another person about issues, including significant ones, while maintaining civility and respecting their right to hold a different view than you, even if you are convinced it is false [5].

Austin also says that Tolerance for many people means something like all views are equally valid, and it is arrogant to think that you have the correct view about something. The problem appears to occur in the context of politics, ethics and the environment. Not only logical, but also confidence in something. Jefferson M. Fish, say that tolerance is much concerned with a person's lifestyle in daily life, of self and the environment [6]. Understanding tolerance can help shift our attitudes toward others, leading us to a more productive and happy life. But he says that "however, the same researchers appear to struggle when examining paradoxical questions such as, 'are tolerant people happier, or are happy people more tolerant"?

From the definition it can be inferred that tolerance is very important to achieve the happiness of life, because of openly attitude, objective, happy. The experts mention a tolerant person more happy or happy people is a tolerant people. Even the experts develop through his research in psychology perspective of tolerance is very closely related to how the brain works faster connect between cells of a person's brain. One's way of thinking is more focused, more sensitive, and quick response [5]. No wonder the social conflict that occurred several cases in the community due to the lack of space in his mind for openness, objective, positive. Self-assessment more prominent so tend to be ethnocentric. Social jealousy more attached to himself and his group against others, so much conflict.

\section{B. Persecution}

Persecution in easy meaning is vigilantism. This means that the judgment or execute en masse against a person or group who are accused of misconduct, with torture, molest, heads, even kill them. On the ancient traditional society, it once was historically the case, conducted based the values and beliefs of the community, such as the value of the beliefs, traditions, religion, and war, racial differences.

Scott Rempell define that Persecusion is the systematic mistreatment of an individual or group by another individual or group [4]. The most common forms are religious persecution, racism and political persecution, though there is naturally some overlap between these terms. The inflicting of suffering, harassment, imprisonment, internment, fear, or pain are all factors that may establish persecution, but not all suffering will necessarily establish persecution. The suffering experienced by the victim must be sufficiently severe.

This view mention of persecution is persecution that systematically against an individual or group by individuals or groups, which are usually a group of religious, tribal, political cause suffering, temptation, punishment, captivity, suffering, pain that is considered wrong. The experience of history shows that the persecution was appointed as international law regarding crimes against humanity.

According to Taylor of Nuremberg principles regarding murder, extermination, enslavement, deportation, and other humanitarian actions removed from civilization, humanity and likewise persecution is considered a war crime. The next development in the Treaty of Rome of persecution identified again by adding other indicators such as gender violence, child abuse and sexual violence, excessive tribal attitude. Other understanding of the persecution that arose from the actions of religious-based era of the Prophet. So, the trend of indicators raises persecution among others with:

- Religion (formerly, and now so human rights issues)

- Ethnic (tribal, regional)

- Genetic

- LGBT

- Military violence

\section{Unity of the nation}

The unity of the nation is a social atmosphere that is created when all citizens feel unified, integrated, emotionally as well as physically. Its main concept is the integration of the social is meant as one of the various social interests, the diversity of cultures, religions, races, tribes that exist. Unity and unity there is usually according to experts due to; goals and ideals are the same, are facing the same problem to be solved, the face the same enemy that must be faced. The process of occurrence of unity according to sociologists, and anthropology through the process of assimilation, acculturation in the life of in the community. Historically the Nations of the world are experiencing a long process of unity of the nation. Before the occurrence of a country, a society in a country that was originally made up of many different tribes, from different regions, Islands, descent, ethnic backgrounds. The split occurred, for a variety of things, whether because of a tribal war causes by different interests. The presence of occupiers of colonialism. Then the Community area was found one region, one nation, and one of the same descent, aiming together to become independent, free to determine its own United against the invaders. Naturally between tribes, between the descendants could establish the process of interaction also between the settlers and the local communities [7]. The villagers who came to town, between the Islands, the entrants with the local tribe, immigrants and the local population. According to Jacob social integration can happen good relationships through interaction in everyday life, such as 'social network, language, and intermarriage'. In work environment people appreciate, understand each other's differences, tolerance, understanding, discussion and differences of national discussion as the nation. Likewise, through intermarriage between tribes, between the descent, as well as marriage among Nations, making it fused with mutual respect and responsibility. The universal way is through education can help create unity, from among a high economic status as well as a low. The results of the study of Rubin, M point out that students in a University can do group work, lecture, both tasks carried out in the campus or outside the 
campus as well [8]. Indonesia is a rich of variety country, tribe, culture, language and traditions but can create unity of the nation by using the principles of:

- Bhinneka Tunggal Ika (Unity in Diversity)

- Nationalism of Indonesia

- Freedom and responsible

- Wawasan nusantara (Insight of the nation)

- Unity and development to realize the reform

The fifth pillar of the Union of the Nations of Indonesia, this being the creation of a unitary nation with depositing of mutual tolerance, appreciate the difference between religious, tribal, linguistic, and different traditions.

\section{METHOD}

Research done on people in Bandung, Kabupaten Bandung, Kabupaten Bandung Barat. By using descriptive study, conducted a survey of opinions and experiences of adult's citizen about persecution. Indicators that analysis is his views/knowledge, tolerance and action undertaken regarding to persecution. The hypothesis that there is a significant relationship between knowledge of persecution and an attitude of tolerance towards the behavior of persecution. Data collecting tool using form, then processed by using scoring 0-4. Highest score 4, 3 score medium, 2 score low, and 1 score is very low, while 0 or there is no positive statement. While the negative questions, score $0=$ the highest value, $1=$ high value, $2=$ medium, $3=$ low Score $=4$ score does not exist. After the given the form a score then put on data tabulations (entry data) in accordance with the format provided. After the data is inserted and then calculated using path analysis with the help of SPSS software (version 24.0). Calculation of description and correlation chronologically each region Kota Bandung, Kabupaten Bandung, Kabupaten Bandung Barat, in the calculation of overall with a label of Bandung Raya.

TABLE I. MODEL 1 DESCRIPTION OF THE SOCIETY OF KOTA BANDUNG DAN KABUPATEN BANDUNG ABOUT PERSECUTION

\begin{tabular}{|l|ll|}
\hline Persecution & a. & knowledge \\
& b. & attitude \\
c. & behavior \\
\hline
\end{tabular}

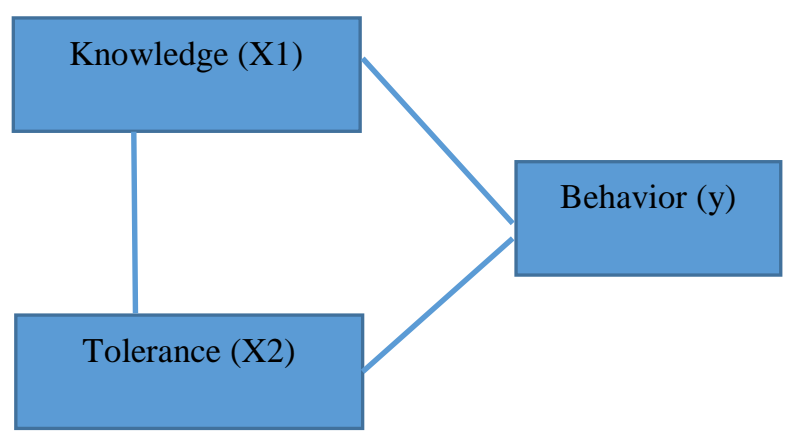

Fig. 1. Model 2. Relationships between variables.

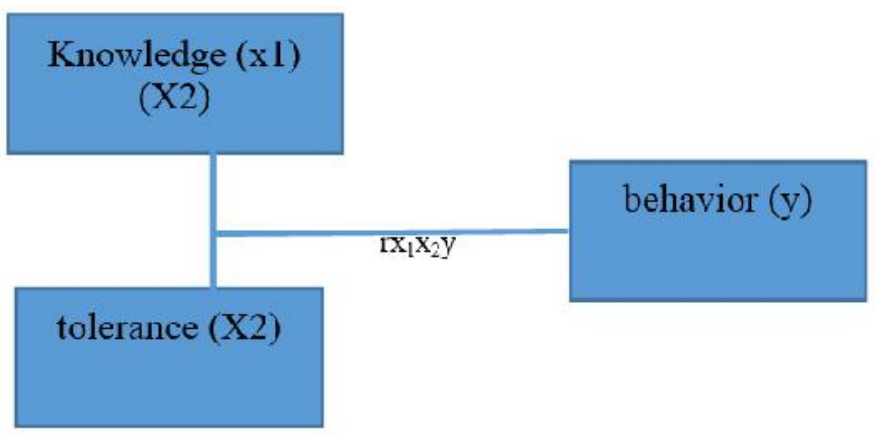

Fig. 2. Model 3. Relationship of multi variables

\section{RESUlT AND DISCUSSION}

The findings of the research results show that the description of the society of Kota Bandung, Kabupaten Bandung, and Kabupaten Bandung Barat, about knowledge, tolerance and tendency of persecution can be seen as follows;

TABLE II. DESCRIPTION OF THE SOCIETY OF BANDUNG AGAINST PERSECUTION OF THE YEAR 2018

\begin{tabular}{|l|l|l|l|}
\hline \multicolumn{1}{|c|}{ Area } & knowledge & tolerance & \multicolumn{1}{c|}{ behavior } \\
\hline Kota Bandung (N=106) & 58,28 & 73,17 & 53,84 \\
\hline $\begin{array}{l}\text { Kab. Bandung Barat } \\
(\mathrm{N}=14)\end{array}$ & 58,48 & 60,27 & 55,35 \\
\hline Kab. Bandung (N=30) & 65,42 & 71,45 & 54,17 \\
\hline Total (150) & 60,73 & 68,30 & 54,45 \\
\hline Ideal Score & 978 & 1241 & 448 \\
\hline
\end{tabular}

From the table above, it can be interpreted that:

- Kota Bandung society's view is quite varied, but from the results of the calculation looks as follows: The interpretation of the description, refer to the Suharsimi IE $40-60 \%$ are at a low category, $61-75 \%$ is high, and $76-100 \%$ very high [9]. According to the table above that level of knowledge was low and the tolerance attitude was high, while the tendency of behavior was still low. In Kabupaten Bandung sees that the knowledge of persecution was quite high Likewise the tolerances is high too, while the tendency of persecution is still low. While the condition in Kabupaten Bandung Barat, knowledge, tolerance and tendency of their behavior are categorized as low. It means the condition is quite well in Bandung, Kabupaten Bandung, and also in Kabupaten Bandung Barat. The threat to unity and the unity of the nation need not be worried if the community has a knowledge about attitude and persecution so there will not be happen any behavior of persecution in the community. The behavior of persecution more due to emotional, and spontaneity of citizens, because when there is an event concerning the violation of the law, the citizens of the community more quickly contacted the nearest police station. Therefore, the efforts of increasing the understanding and attitude of tolerance and persecution continued attempted in 
order to raise awareness between the citizens of the community. The creation of awareness of the norms, rules with reminding each other between citizens, legal socialization, and extension of the law in the community not only reduced persecution, but also at the same time guarantee the creation of unity and national unity.

- The calculation result between the variables have been calculated using SPSS (version 24,0) shows encouraging data as shown below:

TABLE III. THE RESULTS OF THE RELATIONSHIPS BETWEEN VARIABLES IN THE AREA OF BANDUNG

\begin{tabular}{|c|c|c|c|c|c|}
\hline \multirow[t]{2}{*}{ No } & \multirow[t]{2}{*}{ Region } & \multicolumn{4}{|c|}{$\begin{array}{c}\text { The Results of The Relationships Between } \\
\text { Variables }\end{array}$} \\
\hline & & $\begin{array}{l}(X 1)- \\
(X 2)\end{array}$ & $(X 1)-(Y)$ & $(X 2-Y)$ & $\begin{array}{c}(X 1)+(X 2)- \\
(Y) \text { multiple } \\
\text { analysis }\end{array}$ \\
\hline 1 & $\begin{array}{l}\text { Kota } \\
\text { Bandung }\end{array}$ & $\mathrm{R}=0,032$ & $\mathrm{R}=0,039$ & $\mathrm{R}=0,027$ & $\mathrm{R}=0,048$ \\
\hline 2 & $\begin{array}{l}\text { Kabupaten } \\
\text { Bandung }\end{array}$ & $\mathrm{R}=0,290$ & $\mathrm{R}=0.012$ & $\mathrm{R}=0,022$ & $\mathrm{R}=0,029$ \\
\hline 3 & $\begin{array}{l}\text { Kab. } \\
\text { Bandung } \\
\text { Barat }\end{array}$ & $\mathrm{R}=0,459$ & $\mathrm{R}=0,335$ & $\mathrm{R}=0,212$ & $\mathrm{R}=0,342$ \\
\hline 4 & $\begin{array}{l}\text { Total } \\
\text { (Bandung) }\end{array}$ & $\mathrm{R}=0,024$ & $\mathrm{R}=0.029$ & $\mathrm{R}=0,021$ & $\mathrm{R}=0,036$ \\
\hline
\end{tabular}

There was a significant positive relationship between knowledge and attitudes of tolerance of the community of Bandung (0.024) although very small. But the more interesting in Kabupaten Bandung ( $\mathrm{r}=0.290)$, and Kabupaten Bandung Barat $(r=0.459)$, which has a significant positive relationship, but contributed to the tendency of the negative behavior of persecution. This means that the higher the knowledge and attitudes tolerant society will be followed by a declining trend of acts of persecution. When depicted in the matrix below, for example in cases of the Bandung region.

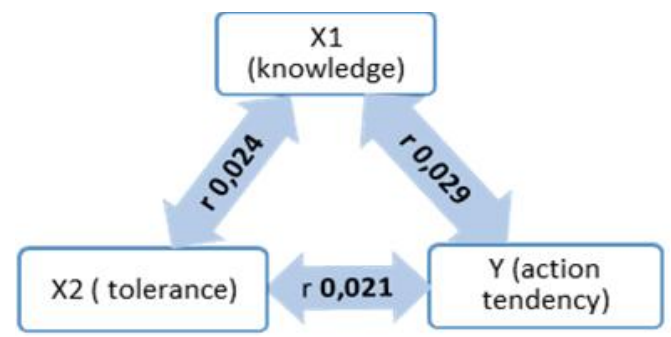

Fig. 3. relationship between knowledge and attitudes of tolerance

There is a relationship between knowledge and attitudes of tolerance, though very little, as well as between the tolerant attitudes and actions of persecution to do small ones. It means an increase in knowledge and attitudes tolerant society, tendencies are followed by decrease in behavior or tendencies of persecution in action community.

Likewise, the analysis between knowledge and attitudes of tolerant toward persecution of the Community action described as follows:

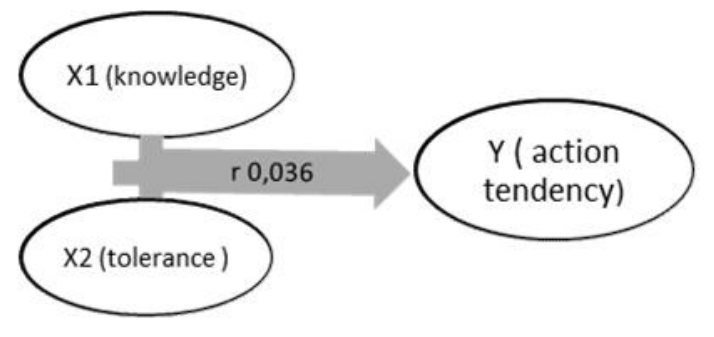

Fig. 4. The analysis between knowledge and attitudes of tolerant toward persecution of the Community action

The existence of knowledge and attitudes Bandung society about persecution shows relationship significant positive with acts of persecution but very little. $(\mathrm{r}=0,036)$, meaning his contribution $(0,036)^{2}=0.001$ very little $1 \%$ even barely exist.

Thus, it could be said that the higher knowledge and attitudes tolerant society against the persecution then tendencies are getting lower to perform acts of persecution. It is rational because the various efforts of the police approach and other related officials promotes attitudes of tolerance and litigious, so don't do the vigilante in the community. Likewise, the more intesive of the police and the security officer which helping a lot in law enforcement and solving the problem. This condition is helping to create safety in the society and also the unity of the nation.

\section{CONCLUSION}

Based on the analysis of data above then it can be inferred that society of Bandung is not too worried about the nation's unity against the result of the attitudes and behaviors of the intolerant persecution in several places in Indonesia. It is wellgrounded because the results of this study showed a few things including; (1) knowledge of the persecution of the community is generally quite good so does the attitude is very good, and the Act of persecution categorized enough. (2) There was a significant positive relationship between knowledge and attitudes of tolerance of the community. (3) There is a negative relationship between knowledge against the behavior of the persecution, it means increased knowledge will be followed with more declining behavior of persecution in the community. (4) There is a negative relationship between the tolerant attitudes of the community towards the behavior of persecution in the community, meaning that the higher the tolerant attitudes in the community then declining levels of persecution in the community. (5) There is a negative relationship between knowledge and attitudes tolerant society against the behavior of the persecution. This means that the higher the knowledge and attitudes tolerant of Bandung society then the descending behavior of persecution in the community. So, it recommended police continue to conduct socialization and the consolidation of security by on alert intensively every day, in order to more quickly handle any social problem, and is able to improve the level of public trust towards the police force itself.

\section{REFERENCES}

[1] Aspinawati, 2017. Perburuan yang Sistematik, Kompas, Jakarta, Nasional.Kompas Kom/red/2017/06/03/13005331. 
[2] Hamdi, M., 2017, Persekusi sebagai Teror yang Mengancam Anak Bangsa, Kompas, Jakarta, Nasional.Kompas Kom/red/2017/06/03/13005331.

[3] Irianto S. Religion, Law and Intolerance in Indonesia. 2017.

[4] Rempell S. Defining persecution. Utah L. Rev. 2013:283.

[5] Austin Michael W., 2011, Ethics for Everyone,True Tolerance, We must understand the true nature of tolerance. Posted Jul 14, 2011 ( 31 Juli 2017)

[6] Fish, Jefferson M., 2017, Psychology Today, Sussex Publishers, LLC HealthProfs.com @ 2002-2017 Sussex Directories, Inc
[7] Vigdor, J., 2008, Measuring Immigrant Assimilation in the United States, Manhattan Institute, New York, Civic Report No. 53 http://dx.doi.org/a0026162.

[8] Rubin, M., 2012, Rubin,M. (2012). Social class differences in social integration among students in higher education: A meta-analysis and recommendations for future research, Journal of Diversity in Higher Education 5, 22-38. doi: 10.1037/a0026162 http://dx.doi.org/a0026162.

[9] Suharsimi, A., 2011. Prosedur Penelitian, Rieneka Cipta. Jakarta, Revision edition. 